\title{
Improvement of Animal Classification Materials Learning Result with Audio Visual Media in Class V Students
}

\author{
Norma Affiani \\ SD Negeri Kowangan \\ rayyametan228@gmail.com
}

\section{Article History}

accepted 14/11/2020

approved 21/11/2020

published 26/11/2020

\begin{abstract}
The purpose of this research was to improve student learning outcomes in science grade $V$ elementary schools with a zoom meeting assisted audio-visual media. The research conducted was a Classroom Action Research (PTK) with three cycles. The stages of each cycle are planning, implementing, observing and reflecting. Each meeting was conducted with a post test to determine the development of students. The condition of student learning completeness before there is action is 32\%. In the first cycle the students who completed after carrying out the post test were $52 \%$. In the second cycle students who completed after carrying out the post test were $72 \%$. In cycle III the students who completed after carrying out the post test were $100 \%$. These results indicate that the use of audio-visual media can improve student learning outcomes, especially grade $V$ science at SDN Kowangan.
\end{abstract}

Keywords: learning outcomes, audio-visual media, science

\begin{abstract}
Abstrak
Tujuan dari penelitian ini adalah untuk meningkatkan hasil belajar peserta didik pada mupel IPA di sekolah dasar kelas $\mathrm{V}$ dengan penggunaan media audio visual berbantuan zoom meeting. Penelitian yang dilakukan adalah Penelitian Tindakan Kelas (PTK) sebanyak tiga siklus. Tahapan setiap siklusnya adalah perencanaan, pelaksanaan, observasi dan refleksi. Setiap pertemuan dilakukan post test untuk mengetahui perkembangan peserta didik. Kondisi ketuntasan belajar siswa sebelum ada tindakan yaitu $32 \%$. Pada siklus I peserta didik yang tuntas setelah melaksanakan post test sebesar $52 \%$. Pada siklus II peserta didik yang tuntas setelah melaksanakan post test sebesar $72 \%$. Pada siklus III peserta didik yang tuntas setelah melaksanakan post test sebesar $100 \%$. Hasil ini menunjukan bahwa peggunaan media audio visual dapat meningkatkan hasil belajar peserta didik khususnya mupel IPA Kelas V di SDN Kowangan.
\end{abstract}

Kata kunci: Hasil belajar, media audio visual, IPA 


\section{PENDAHULUAN}

Tujuan pembelajaran IPA di SD disamping untuk mengembangkan pengetahuan dan pemahaman konsep-konsep IPA yang dapat diterapkan dalam kehidupan seharihari, juga mengembangkan keterampilan proses untuk menyelidiki alam sekitar, memecahkan masalah dan membuat keputusan. Tujuan tersebut dicapai dengan cara mengajarkan IPA yang mengacu pada hakikat IPA dan menekankan pada pemberian pengalaman langsung untuk mengembangkan kompetensi siswa.

Melihat beragamnya media yang dapat dipergunakan guru, sudah seharusnyalah seorang guru mampu dan mau menggunakan berbagai media untuk memanipulasi keabstrakan materi yang disampaikan kepada peserta didik. Namun kenyataan dilapangan dari hasil refleksi yang peneliti lakukan di Sekolah Dasar Negeri Kowangan khususnya untuk kelas $\mathrm{V}$ pada pembelajaran mata pelajaran IPA, proses belajar mengajar di kelas hanya dilakukan dengan metode konvensional. Guru banyak bercerita atau berceramah tanpa melibatkan peserta didik secara aktif dalam kegiatan pembelajaran tersebut, sehingga rasa ingin tahu peserta didik tidak terbangun, kemandirian dalam kegiatan pembelajaranpun sedikit sekali terbentuk. Hal tersebut berpengaruh secara langsung pada hasil belajar peserta didik.

Kenyataan yang ditemui di lapangan terdapat permasalahan dalam pembelajaran antara lain: bahwa kegiatan pembelajaran belum dimulai dengan permasalahan, guru belum memotivasi siswa untuk terlibat aktif dalam pemecahan masalah, belum melaksanakan penyelidikan guna mendapatkan informasi, guru belum membimbing siswa menyiapkan karya yang sesuai, siswa belum mempresentasikan hasil karya, kurangnya media yang menumbuhkan minat dan motivasi siswa serta mudah diingat. Berdasarkan pengalaman penulis di lapangan, kegagalan dalam belajar rata-rata dihadapi oleh sejumlah siswa, dikarenakan kebanyakan seorang guru mengajar dengan metode ceramah sehingga membuat siswa tidak termotivasi untuk belajar. Dikarenakan kurangnya motivasi belajar sehingga membuat mereka enggan untuk memperhatiakan, malas mengerjakan tugas dan PR, bermain ketika belajar. Sehingga hasil belajar siswa tidak tuntas. Untuk itu dibutuhkan suatu kegiatan yang dilakukan oleh guru dengan upaya membangkitkan motifasi belajar siswa, misalnya dengan membimbing siswa untuk terlibat langsung dalam kegiatan yang melibatkan siswa serta guru yang berperan sebagai pembimbing untuk menemukan konsep IPA.

Piaget (dalam Sujana, 2014, hlm. 27) membagi skema yang digunakan anak untuk memahami dunianya melalui empat periode utama, yaitu periode sensorimotor (0-2 tahun), periode praoperasional (7-7 tahun), periode operasional konkrit (7-11 tahun), serta periode operasional formal (11 tahun sampai dewasa). Pada periode operasional konkret berangsung sekitar 7-11 tahun. Pada usia ini adalah usia anak sekolah SD. Pada usia ini pikiran logis anak mulai berkembang dan mulai menggali informasi tentang lingkungannya tidak dengan panca inderanya saja. Anak pada usia ini sudah dapat berpikir secara operasi konkret. Anak telah dapat melakukan klasifikasi, pengelompokan dan pengaturan masalah.

Penggunaan media audio visual dapat mempertinggi perhatian anak dengan tampilan yang menarik. Selain itu, anak akan takut ketinggalan jalannya video tersebut jika melewatkan dengan mengalihkan konsentrasi dan perhatian. Media audio visual yang menampilkan realitas materi dapat memberikan pengalaman nyata pada siswa saat mempelajarinya sehingga mendorong adanya aktivitas diri. Fungsi Media Pembelajaran Menurut Oemar Hamalik (dalam Musfiqon, 2012, hlm. 32), "pemakaian media pembelajaran dalam proses belajar mengajar dapat membangkitkan keinginan dan minat yang baru, membangkitkan motivasi dan rangsangan kegiatan belajar, dan bahkan membawa pengaruh-pengaruh psikologis terhadap siswa." Pesan 
pembelajaran yang disampaikan guru tanpa menggunakan media akan terasa hambar dan tidak akan membekas jika tidak menggunakan media. Begitupun semangat siswa untuk belajar sangat rendah bahkan bisa dikatakan tidak ada. Ketika pembelajaran sudah mencapai titik jenuh dan tidak ada semangat siswa untuk melanjutkan kegiatan belajar, maka kehadiran sebuah media akan terasa sangat membantu dan sangat diperlukan.

Yusufhadi Miarso (2004) mengartikan media sebagai segala bentuk dan saluran untuk proses transmisi informasi. Apabila media itu membawa pesan atau informasi yang bertujuan instruksional atau mengandung maksud-maksud pengajaran, maka media itu disebut media pembelajaran. (Azhar Arsyad, 2005).

Menurut Azhar Arsyad (2010 : 3)mengungkapkan media audio visual yaitu media yang dapat dilihat sekaligus dapat didengar, seperti film bersuara, video, televisi, sound slide yang digunakan untuk menyampaikan pesan atau informasi.

Tujuan menggunakan media audio visual sebagai berikut (a) Meningkatkan hasil belajar siswa, (b) Menunjukkan contoh cara bersikap, atau berbuat dalam suatu penampilan, khususnya yang menyangkut interaksi manusiawi dan proses pembuatan suatu produk, (c) Mempengaruhi sikap dan emosi. (d) Menampilkan contoh keterampilan yang menyangkut gerak, (e) Menonton bersama-sama untuk membangun kesamaan persepsi dalam proses belajar mengajar.

Menurut Sobry (2008: 102-103) bahwa ada beberapa manfaat media audio visual dalam proses belajar mengajar, di antaranya, (a) Menarik perhatian siswa, (b) Membantu untuk mempercepat pemahaman dalam proses pembelajaran, (c) Memperjelas penyajian pesan agar tidak bersifat verbalitas, (d) Mengatasi keterbatasan ruangan, (e) Pembelajaran lebih komunikatif, (f) Waktu pembelajaran bisa di kondisikan (g) Menghilangkan kebosanan siswa dalam belajar, (h) Meningkatkan motivasi siswa dalam belajar, (i) Melayani gaya belajar siswa yang beraneka ragam,(j) Meningkatkan kadar keaktifan/keterlibatan siswa dalam kegiatan pembelajaran.

\section{METODE}

Penelitian ini adalah penelitian tindakan kelas (Classroom Action Research) dengan menerapkan penggunaan media audio visual. Menurut Kurt Lewin dalam Kunandar (2011: 42) penelitian tindakan kelas ini terdiri dari empat tahapan dasar yaitu perencanaan (planning), pelaksanaan (acting), pengamatan (observing) dan refleksi (reflecting). Analisis penelitian ini adalah analisis deskriptif kuantitafif kualitatif dimana dalam penelitian ini selain penyajian hasil berupa data maupun angka peneliti juga menentukan bagaimana cara pengolahan hasil penelitian yakni dengan membuat analisisnya dengan menerapkan media audio visual dalam pembelajaran. Penelitian ini dilaksanakan pada peserta didik kelas V SD Negeri Kowangan Tahun Pelajaran 2020/2021 selama tiga siklus secara daring menggunakan aplikasi Zoom meeting. Siklus I dilaksanakan pada tanggal 2 November 2020. Siklus II dilaksanakan pada tanggal 9 November 2020. Siklus III dilaksanakan pada tanggal 20 November 2020. Teknik pengumpulan data yang dilakukan dengan observasi dan tes. Observasi meliputi observasi penguasaan kinerja guru, sikap peserta didik dan keterampilan, serta observasi mengenai penggunaan metode. Untuk hasil belajar menggunakan tes melalui Google form.

\section{HASIL DAN PEMBAHASAN}

Penelitian ini dilakukan berdasarkan dari permasalahan-permasalahan yang muncul dikelas. Permasalahan umumnya adalah belum meningkatnya aktivitas belajar 
siswa dan hasil belajar dalam pembelajaran IPA. Penelitian ini dilaksanakan sebanyak 3 siklus yaitu siklus 1 tanggal 2 November 2020, siklus 2 tanggal 9 November 2020, dan siklus 3 tanggal 20 November 2020. Setiap siklus dilaksanakan satu kali pertemuan dengan materi menyesuaikan pada kondisi pembelajaran.

Pada hasil siklus 1 terdapat kekurangan yaitu sebagai berikut : (a) Peneliti kurang mampu membimbing siswa sehingga tidak sesuai dengan apa yang direncanakan di dalam RPP, (b)Peneliti sulit dalam membimbing siswa dalam mengklarifikasi nilai-nilai yang terdapat dalam pembelajaran, (c)Pelaksanaan waktu pembelajaran lebih lama dari yang direncanakan, (d) Siswa masih belum mengerti cara mengklarifikasi pertanyaan-pertanyaan,(e) Hasil belajar siswa belum mencapai ketuntasan.

Setelah mengetahui kekurangan pelaksanaan tindakan atau proses pembelajaran pada siklus 1, kemudian bersama-sama kembali merencanakan tindakan yang akan dilakukan untuk memperbaiki kekurangan-kekurangan yang ada. Kekurangan-kekurangan yang muncul akan diperbaiki pada siklus selanjutnya yaitu pada siklus 2 .

Pada hasil siklus 2 terdapat kekurangan yaitu sebagai berikut : (a) Hasil Belajar siswa sudah menunjukkan peningkatan akan tetapi harus di perbaki kembali karena masih siswa yang mendapat nilai rendah, (b) Masih ada beberapa siswa yang kurang aktif pada saat pembelajaran. Tetapi itu tertutupi karena frekuensinya sedikit. (c) Tidak total $100 \%$ siswa keseluruhan aktif.

Setelah mengetahui kekurangan pelaksanaan tindakan atau proses pembelajaran pada siklus 2, kemudian bersama-sama kembali merencanakan tindakan yang akan dilakukan untuk memperbaiki kekurangan-kekurangan yang ada. Kekurangan-kekurangan yang muncul akan diperbaiki pada siklus selanjutnya yaitu pada siklus 3.

Adapun kelebihan pada siklus 3 sebagai berikut: (a) Terjadi peningkatan hasil belajar yang signifikan secara keseluruhan, (b) Guru menguasai materi pembelajaran dan sudah menguasai secara keseluruhan pembelajaran dengan menggunakan media audio visual,(c) Dalam siklus 3 ini hampir semua siswa terlibat aktif dalam proses pembelajaran,(d)Siswa secara keseluruhan sudah memahami proses pembelajaran yang dilakukan dengan menggunakan media audio visual sehingga proses pembelajaran menjadi menyenangkan.

Setelah melakukan 3 siklus penelitian pada pembelajaran IImu Pengetahuan Alam Kelas V SDN Kowangan Kabupaten Temanggung dengan menggunakan media audio visual yang dilakukan oleh peneliti, diperoleh rekapitulasi hasil belajar siswa kelas V SDN Kowangan Kabupaten Temanggung adalah sebagai berikut:

Tabel 1. Rekapitulasi Hasil Belajar Peserta Didik Kelas V

\begin{tabular}{ccccc}
\hline \multirow{2}{*}{ No } & \multirow{2}{*}{ Siklus } & Banyak Siswa & \multicolumn{2}{c}{ Nilai } \\
\cline { 4 - 5 } & & & Tuntas & Tidak Tuntas \\
\hline 1 & \multirow{2}{*}{ Siklus I } & 25 & 13 & 12 \\
& & & $52 \%$ & $48 \%$ \\
\hline 2 & Siklus II & 25 & 18 & 7 \\
& & & $72 \%$ & $28 \%$ \\
\hline 3 & Siklus III & 25 & 25 & 0 \\
& & & $100 \%$ & $0 \%$
\end{tabular}

Berdasarkan table diatas, pada siklus I terdapat 13 siswa yang mendapat nilai tuntas, dengan ketuntasan belajar siswa sebesar $52 \%$, siklus II mengalami peningkatan sebesar $20 \%$, yaitu terdapat 18 siswa yang mendapat nilai tuntas dengan ketuntasan belajar siswa sebesar $72 \%$, dan siklus III ketuntasan belajar siswa mengalami peningkatan menjadi $100 \%$ artinya semua siswa tuntas dalam hasil belajarnya. Untuk lebih jelasnya bisa dilihat pada grafik berikut 


\section{Garfik 1. Rekapitulasi Hasil Belajar Peserta Didik Kelas V}

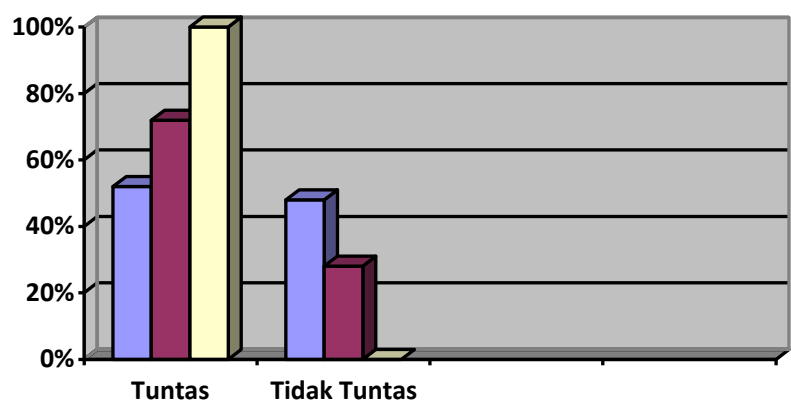

Meningkatnya hasil belajar siswa pada siklus III dibandingkan pada Pra siklus, siklus 1, dan siklus 2 menunjukkan bahwa dengan menggunakan media audio visual dapat meningkatkan prestasi belajar siswa diatas KKM. Yakni dengan rata- rata 86,8 dengan katagori baik sekali

Tabel 2. Hasil Kegiatan Pembelajaran Pada Siklus I, II, dan III

\begin{tabular}{llcccc}
\hline No & $\begin{array}{c}\text { Aspek Indikator } \\
\text { Keberhasilan }\end{array}$ & Siklus I & Siklus II & Siklus III & Ket \\
\hline 1 & Aktivitas guru & $75 \%$ & $85 \%$ & $100 \%$ \\
2 & Aktivitas siswa & $76,5 \%$ & $87 \%$ & $95 \%$ & \\
3 & Hasil Belajar siswa & 75,8 & 83,2 & 86,8 & \\
& a. Rata-rata & $52 \%$ & $72 \%$ & $100 \%$ & \\
& $\begin{array}{l}\text { b. Persentase } \\
\text { ketuntasan Klasikal }\end{array}$ & & & & \\
& & &
\end{tabular}

Grafik 2.

Hasil Kegiatan Pembelajaran Pada Siklus I, II, dan III

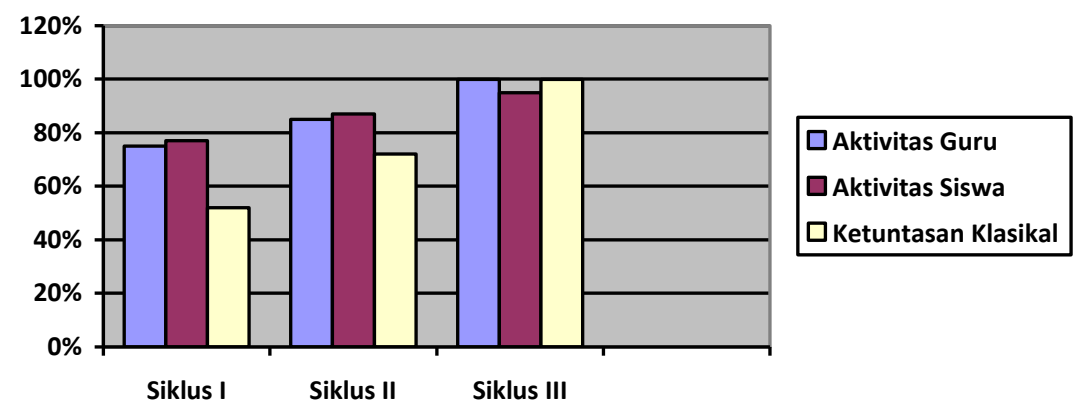

Aktivitas guru pada siklus III ini terlihat semakin baik dan semakin meningkat. Guru lebih siap dengan pernik-pernik penunjang keberhasilan dan kelancaran pembelajaran. Guru dalam menyampaikan tujuan pembelajaran lebih mengarah ke maksud dengan bahasa yang mudah dan sederhana sehingga lebih dapat dimengerti. Motivasi lebih sering diberikan yaitu pada setiap saat diperlukan, lebih bervariasi dan lebih bermakna (sesuai dengan momen saat itu). Ulasan kegiatan disampaikan lebih detail / lebih rinci dan diulang-ulang sampai siswa paham,

Aktivitas siswa pada siklus III inipun telah mencapai target yaitu 95\% dari target yang diharapkan yaitu $\geq 80 \%$. Hal itu terjadi karena pada siklus III ini siswa yang kurang memperhatikan/ kurang tertib berkurang yaitu dari 5 siswa menjadi 3 siswa, itupun 
tidak sepanjang proses pembelajaran ketidaktertibannya, hanya pada saat-saat tertentu saja, saat perhatian mereka mulai bergeser, dan guru senantiasa paham akan kondisi tersebut dan segera mengajak mereka untuk berkonsentrasi kembali, dengan demikian aktivitas siswa dapat selalu terjaga

Pada siklus III inipun menunjukkan peningkatan. Target nilai rata-rata kelas telah tercapai, sebab pada siklus III ini nilai rata-rata kelas telah mencapai 86,8 , sedang prosentase ketuntasan belajar mencapai 100\%. Dari 7 anak yang nilainya di bawah rata-rata pada siklus II, pada siklus III ini semua siswa bisa mencapai ketuntasan. Hal itu terjadi karena pada siklus III ini anak sudah lebih memperhatikan proses pembelajaran, disamping guru juga terus mengkondisikan proses pembelajaran tersebut dengan maksimal, sehingga indikator ketuntasan hasil belajar siswa bisa tercapai.

Dari tiga siklus yang sudah dilaksanakan dapat dipastikan bahwa penggunaan media audio visual dapat meningkatkan hasil belajar peserta didik pada mupel IPA Kelas V di SD N Kowangan. Hal ini sesuai dengan pendapat Musfiqon (2012, hlm. 187) yang mengemukakan bahwa "...pembelajaran yang menggunakan multimedia telah terbukti lebih efektif dan efisien serta bisa meningkatkan hasil belajar siswa". Media audio visual termasuk dalam multimedia yaitu jenis media yang selain mengandung unsur suara juga mengandung unsur gambar yang dapat dilihat, seperti misalnya rekaman video, berbagai ukuran film, slide suara dan lain sebagainya. Pada penggunaan media audio visual disini menggunakan rekaman video. Hal ini dapat memudahkan siswa dalam memahami materi penggolongan hewan saat pembelajaran berlangsung. Media audio visual dapat memberikan pengalaman yang bermakna yang belum pernah dilihat sebelumnya dan dapat meningkatkan gairah belajar pada siswa serta memudahkan siswa dalam memahami sesuatu yang abstrak menjadi sesuatu yang kongkrit seperti yang dikemukakan oleh Benni Agus Pribadi (dalam Musfiqon 2012), media pembelajaran berfungsi untuk membantu memudahkan belajar bagi siswa dan juga memudahkan proses pembelajaran bagi guru, memberikan pengalaman lebih nyata (abstrak menjadi konkret, menarik perhatian siswa lebih besar (jalannya pelajaran tidak membosankan), semua indera siswa dapat diaktifkan, dapat membangkitkan dunia teori dengan realitanya

\section{SIMPULAN}

Berdasarkan hasil pembahasan dan analisis diatas dapat di simpulkan bahwa melalui penggunaan media audio visual pada mata pelajaran IPA dapat meningkatkan aktivitas belajar siswa kelas V SD N Kowangan, diketahui bahwa rata rata keaktifan siswa menjadi lebih baik jika di bandingkan dengan sebelum di terapkannya strategi pembelajaran tersebut,di mana sebelumnya ketuntasan hasil belajar di peroleh nilai jumlah 1.650 dengan rata rata 66 dan persentase $32 \%$.

Pada siklus pertama I siswa yang tuntas 13 dan yang tidak tuntas 12 dengan di peroleh nilai rata rata 75,8 dan persentase $52 \%$ secara kelasikal belum mencapai standar keberhasilan namun sudah lebih meningkat dibandingkan saat fase pra siklus. Untuk lebih memperkuat bahwa media powerpoint dan video pembelajaran dapat meningkatkan hasil belajar maka peneliti mengadakan siklus kedua dengan memperoleh ketuntasan yakni 17 siswa tuntas dengan jumlah nilai 2.080 dengan nilai rata-rata 83,2 dan persentase $72 \%$. Kemudian dilanjutkan dengan siklus III ternyata hasil ketuntasan belajar siswa meningkat lagi dengan jumlah nilai 2.170 dengan nilai rata-rata 86,8 dan persentase $100 \%$. Dengan demikian di nyatakan berhasil dalam melakukan proses pembelajaran IImu Pengetahuan Alam di kelas V SD N Kowangan. 


\section{DAFTAR PUSTAKA}

Arsyad. (2005). Media Pembelajaran. Jakarta: PT. Raja Grafindo Persada, hlm.4. Depdiknas. (2003). Undang-undang RI No.20 tahun 2003 tentang sistem pendidikan nasional.

M. Sobry Sutikno. (2003). Menuju Pendidikan Bermutu. Mataram: NTP Press.

Miarso, Yusuf hadi. (2004). Menyemai Benih Teknologi Pendidikan. Jakarta: Kencana Prenada Media Group

Nana Sudjana. (2013). Penilaian Hasil Proses Belajar Mengajar. Bandung: Remaja Rosdakarya.

Riana, Cepi. (2008). Media Pembelajaran dalam Asia, dkk (editor) Komputer dan Media Pendidikan di Sekolah Dasar. Direktorat Jendral Pendidikan Tinggi, Departemen Pendidikan Nasional

Rusman. (2014). Model-Model Pembelajaran. Jakarta: Rajawali Pers

Suprihatiningrum, Jamil. (2014). Strategi Pembelajaran: Teori dan aplikasi. Jogjakarta: Ar-Ruzz Media 